\title{
Translation and editing: A study of editorial treatment of nominalisations in draft translations
}

\author{
Mario Bisiada \\ Universitat Pompeu Fabra \\ mario.bisiada@upf.edu
}

(Received Aug 2016; final version received Nov 2016)

\begin{abstract}
Though editing and revising are integral parts of translation, their effects on the language of the final translated text has scarcely been studied. Phenomena we observe in translated text are usually attributed to 'the translator', even though the multitude of agents involved in translation may also be responsible for them to various degrees. This paper promotes the use of manuscripts in corpus-based translation studies by investigating differences in nominalisation between unedited and edited translations. Using a corpus of manuscript and published German translations of English business articles, I investigate what may motivate editors to replace a nominalisation in the translation manuscript by a verb to match the English source text. For this purpose, I analyse differences in the process types of the nominalised source text verbs and the structure and information density of the nominal group the nominalisation appears in. The findings show that editors take extensive and systematic influence on the translated text. Crucially, the analysis shows that studies that only consider the published version of a translation often mistake for a literal translation a sentence that has undergone a considerable amount of shifts while passing through the stages of translation.
\end{abstract}

Keywords: Editing; corpus-based translation studies; applied translation; professional translation; translating style

\section{Introduction}

In his chapter entitled 'interim solutions', Toury (1995) criticised the method of comparing source and target text because it

entails an inherent weakness precisely as far as translation processes are concerned. As long as it is only pairs of target vs. source texts that are available for study, there is no way of knowing how many different persons were actually involved in the establishment of a translation playing how many different roles. Whatever the number, the common practice has been to collapse all of them into one person and have that conjoined entity regarded as 'the translator' (Toury, 1995, p. 183).

This criticism still holds true today. Translation revision and editing by others are part of translators' daily lives (Mossop, 2007; Mossop, 2001/2014), yet those activities have not attracted much empirical research. Hardly any study has thus far analysed the linguistic changes made by editors to translated manuscripts in the process of producing a translation. Instead we usually take

This work was funded by the Spanish Ministerio de Economía y Competitividad, under the project entitled ModevigTrad: Evidentiality and epistemicity in texts of evaluative discourse genres. Contrastive analysis and translation (FFI2014-57313-P). 
for granted that the translations we use for our research really represent the text that the translator produced, ignoring all the intervening agents that may have changed the text before its publication.

This paper analyses editorial action through a qualitative study of nominalisations in EnglishGerman translation. The aim is to find out what influences editors' decisions to maintain or change translators' nominalisations. To try and discover possible motivations for this, two phenomena will be investigated: the process type of the source text verb (Section 4.2) and the information density of the translation (Section 4.3), operationalised by the depth of pre- and post-modification of the nominal group.

\section{Manuscripts in corpus-based translation studies}

Product-oriented research of translations often necessarily relies on published sources. Indeed, the use of corpora in translation studies derives its empirical strength largely from the fact that it analyses what has been variously termed 'actual translated texts-in-function' (Holmes, 1988, p. 101), 'real data' (Baker, 1993, p. 237), 'language as it is used in the translation product' (Olohan, 2004, p. 16) or 'authentic data, as attested in texts' (Kenny, 2009, p. 59). Relying solely on published sources, however, renders us unable to consider changes made to the manuscript translations before publication.

Some research exists on the effects of editing in non-translated language. For instance, Manenti (2010) investigates the role of editors in shaping the reception of books. Purcell, Donovan and Davidoff (1998) have analysed changes to seven articles during the editing and peer review process in the Annals of Internal Medicine to study objective changes to content enhancing their acceptability as scientific articles. Sometimes, the extent of editorial influence on the text is obvious even without access to manuscripts, as Eve's (2016) analysis of the US and UK editions of David Mitchell's Cloud Atlas shows.

Several studies in the field of second language writing have also drawn on the analysis of manuscripts. Questioning how much published articles reflect the author's voice, Burrough-Boenisch (2003) studies the actions, reactions and interactions of 'pre-publication readers' or 'shapers' such as reviewers, journal editors and copyeditors on research articles written by non-native speakers from draft to publication. She argues that the published text is a 'product of the publishing industry, as well as a product of, and for, a particular discourse community' (Burrough-Boenisch, 2003, p. 224). She concludes that one should be 'wary of characterising non-native speaker written discourse on the basis of an analysis of published non-native speaker texts' (Burrough-Boenisch, 2003, p. 239).

Similarly, Harvey (2003) studies ideology in the 'bindings' of three 1970s gay fictional texts translated from English to French, showing that different ideologies and understandings of the homosexual compete in those 'bindings'. In his conclusion, he argues that 'in-house editorial policies make it dangerous to assume that the translator as individual [...] is singly responsible for textual outcomes even in the main body of the text' (Harvey, 2003, p. 69). These insights hold true also for corpus-based translation studies, as we should be wary of characterising translated discourse on the basis of an analysis solely of published translated texts.

One of the first to suggest the analysis of translated documents at several stages in their development was Hartmann (1981, p. 206). He suggested 'multiphase comparisons' and the analysis 
of 'successive stages' of 'individual attempts' at translations, analysing changes to a passage of the English translation of Erich Maria Remarque's Im Westen nichts Neues through its various stages from manuscript via proof to the pre-print stage (Hartmann, 1980, p. 109; Hartmann, 1981, p. 206).

Somewhat later, in a seminal article proposing the use of corpora in translation studies, Baker (1993, p. 247) discusses the 'question of the intermediate stages of translation, or how the final product evolves over a period of time'. She argued that 'access to this type of text in electronic form can be used to explore the process of translation through a retrospective analysis of successive versions of the product' (Baker, 1993, p. 247).

Such methodological analyses of the translation process are still used today to inform research in literary translation (see Jansen \& Wegener, 2013). Thus, Filippakopoulou (2008) discusses the use of translation drafts in translation criticism and Munday (2013) proposes the use of manuscripts to investigate decision-making in translation. He argues that 'unpublished primary sources preceding and building to the [target text] itself' are a 'valuable window into the working practice of a translator' (Munday, 2013, p. 126).

Sinner (2012) studies fictive dialogue in 26 romance novels published between 2003 and 2009. His corpus includes English source texts, their German manuscript translations as well as the published translations (Sinner, 2012, p. 136). The analysis shows significant editorial changes to the translations with regard to terms of address and the explicitness of language. Editorial guidelines are strictly enforced, to the extent that style often seems more important than correctness: for instance, editors require that nominal terms of address such as titles be maintained despite their unnatural appearance in the German text (Sinner, 2012, p. 126). Editors also intervene to eliminate swear words and sexual references, even though translators had already toned them down, so that the dialogue, 'especially in sex scenes, is far from representing credible orality' (Sinner, 2012, p. 133).

In what he calls a 'phases of translation' corpus, Utka (2004, p. 197) compiled 'successive written draft versions' of EU documents translated from English to Lithuanian. The stages of the text available to him are the 'first translator's draft', the 'second-edited draft' and the 'final version' (Utka, 2004, p. 198). Unfortunately, he does not discuss the people involved in the translation process, so we do not know whether the translators revised the texts themselves or whether someone else did. As his paper is primarily a methodological one, findings are sparsely interpreted and restricted to the lexical level, where the author observes that the revision stage introduces terminological consistency. Utka notes a reduction of different expressions ('types') during the editing stage, from which he deduces a 'normalisation of lexis' (Utka, 2004, p. 207) in the course of the translation process. A few pages later, however, he also notes an increase in the variety of Lithuanian translations of according to due to intervention by the editors, contradicting his previous observation (Utka, 2004, p. 218). A further drawback of this study is that the texts discussed are EU documents, which are relatively 'ephemeral' (Mossop, 2001/2014, p. 136), written for rapid publication and designed for singular consultation by a small set of readers, and thus not subject to detailed editing as would be the case with a text designed for mass publication.

Kruger (2012, p. 383) investigates 'the hidden mediating effect of editing on original, unmediated text production' by analysing the treatment of three proposed universals of translation (normalisation, explicitation and simplification) in 'mediated language' (translated text and edited text) 
and 'unmediated language' (unedited text). To study the three universals of translation, she looks at a range of linguistic features, for instance, lexical diversity and mean word length to study simplification (for the full list, see Kruger, 2012, p. 362). In the analysis, she draws on a 1.2 million word corpus of 'academic, instructional, popular and reportage' texts, which consists of a translation subcorpus (containing texts translated from Afrikaans to English), an edited subcorpus and an unedited subcorpus of English (Kruger, 2012, pp. 359-360).

Kruger finds no evidence for a mediation effect shared by translated and edited text (2012, pp. 380-382), but instead notes that 'editors introduce collocational variety' whereas translators favour 'explicit and standardised language' (Kruger, 2012, p. 382). This supports Utka's (2004, p. 218) findings on Lithuanian translations of according to reported above. As for the proposed similarity between translated and edited text, Kruger concludes that editing 'does not appear to involve explicitation and simplification to the degree evident in translated language' (Kruger, 2012, p. 382).

Similarly, in a study of editorial intervention in the Spanish translation of a French novel, Andújar Moreno (2016) finds that a range of changes can be attributed to editors' attempts at increasing the readability of the text. Readability also plays a role in the analysis of sentence splitting in translation, where Bisiada (2016) argues against the notion that sentence splitting is a phenomenon that occurs only in particular translation directions. He finds that sentence splitting is frequent in English-German translation of business articles, and that it is not just translators that engage in it, but also editors to a significant extent.

The studies discussed in this section show that it may be misleading to talk about features of 'translated language' while only considering published translations. Often, phenomena we encounter may also be caused by other agents intervening in the translated text. Editorial intervention, then, is significant enough to warrant greater attention in translation studies.

\section{Studying editorial intervention through corpora}

The object of analysis in this paper is the treatment of nominalisations by editors in EnglishGerman business translation. The texts under analysis are articles published from 2006 to 2011 in the monthly American magazine Harvard Business Review. They were translated by the translation company Rheinschrift and then sent to the editors at the Harvard Business Manager, where they were eventually published.

My analysis draws on a tripartite parallel corpus of 316,000 words 'in which two or more components are aligned and can thus be retrieved as [...] triplets' (Fantinuoli \& Zanettin, 2015, p. 4). This allows for a comparative analysis of the translation manuscripts and the published versions of those manuscripts. From this corpus, I selected all the sentences where the source text contains a verb that the translator nominalised. This was done by searching for the German nominalisation morphemes -ung and -ieren. This set of sentences was then manually inspected to filter out only those instances where the editor either maintained the nominalisation or changed it by reverbalising the construction. The resulting dataset is a corpus of 11,000 words, a good basis for qualitative study.

Deverbal nominalisations are a relevant phenomenon to study because they are the most frequent part-of-speech shift in translations from English to German (Alves, Pagano, Neumann, Steiner \& 
Hansen-Schirra, 2010, p. 116). This is due to the fact that the nominal style is considered to be preferred in German (Fabricius-Hansen, 1999, p. 203; Hansen-Schirra, Hansen, Wolfer \& Konieczny, 2009 , p. 112; Krein-Kühle, 2003, p. 160). It is thus interesting to investigate to what extent translators and editors engage in nominalisation because the guidelines for translators specifically request translators to avoid the nominal style. At the Harvard Business Manager, nominalisations are among the things that editors pay attention to when working on the texts, according to Britta Domke, one of the magazine's editors (personal communication, 31 March, 2015):

\begin{abstract}
Auch sprachlich arbeiten wir zum Teil noch stark an den Übersetzungen, je nach Qualität und Engagement des jeweiligen Übersetzers. So zerhacken wir Bandwurmsätze in leichter verständliche Einzelteile, formulieren Substantivierungen und Passivkonstruktionen um und streichen überflüssige Hilfsverben.
\end{abstract}

['We also edit the language of the translations, at times significantly, depending on the quality and effort of each translator. Thus, we split convoluted sentences into more comprehensible pieces, reformulate nominalisations and passive constructions and remove superfluous auxiliary verbs.']

The editors at the Harvard Business Manager are not themselves translators, but have a journalistic background. Nevertheless, they always refer to the source text while working on the translation (Britta Domke, personal communication, 31 March 2015):

Wenn wir mit der Redigatur eines übersetzten Textes beginnen, legen wir uns in der Regel den Originaltext aus der HBR daneben und vergleichen beides Satz für Satz, sowohl sprachlich als auch inhaltlich.

['When we start editing the translated text, we usually place next to us the original text from the HBR and compare both texts sentence by sentence, with regard to both language and content.']

The decision to nominalise or verbalise a construction does not always represent a choice. Sometimes, language contrasts specify the use of nouns or verbs. For instance, in English, the verb phrases create value or add value are commonly used. Translators working into German do not really have a verbal equivalent at their disposal. Instead, they tend to use the noun Wertschöpfung ('value creation', 'added value'). There are just two instances of such a verbal form in the present corpus (see example (1)). The DWDS, a German newspaper reference corpus, also shows just one instance for the lemma Wert schöpfen. If the phrase is used, it may well be a calque based on the English expression.

(1) So if there is some chance that a deal between a buyer and a seller can create extra value, it's better to negotiate than to hold an auction. (HBR 12/09,101) 
Wenn also die Möglichkeit besteht, dass ein Verhandlungsabschluss zwischen einem Käufer und einem Verkäufer zu einer zusätzlichen Wertschöpfung führt, sollten Verhandlungen statt Versteigerungen stattfinden. (manuscript)

['If there is a possibility that the closing of a deal between a buyer and a seller will lead to an extra value creation, negotiations rather than auctions should take place.']
Wenn also die Möglichkeit besteht, dass ein Geschäftsabschluss zwischen einem Käufer und einem Verkäufer im Fall von Verhandlungen zusätzlichen Wert schöpft, sollten Sie verhandeln, anstatt eine Auktion durchzuführen. (HBM $6 / 10,74)$

['If there is a possibility that the closing of a deal between a buyer and a seller will create extra value in the case of negotiations, you should negotiate instead of conducting an auction.']

\section{Analysis}

\subsection{Introduction}

There are 541 instances of nominalisation by translators. Of those, 339 were retained in the published document, but 202 were changed to verbs by the editors. In what follows, I will attempt to find possible linguistic motivations for the editors' decisions. Two approaches will be used: The process type of the source text verb and modification of the nominalisation in the nominal group. The two hypotheses that are investigated in this section are that a nominalised metaphorical expression is likely to be unpacked

(1) according to the process type of the source text verb, as some process types are more acceptable as nominalisations to the editor than others (Section 4.2);

(2) if the nominalisations in the manuscripts receive pre- or postmodification, as this increases the information density of the sentence (Section 4.3).

\subsection{Process types}

Processes are usually expressed as verbs, but may be metaphorically expressed as nouns in deverbal nominalisations (Heyvaert, 2003, p. 66). In the study of editors' decisions as to whether particular processes are acceptable in their nominalised form or whether they are better expressed as verbs, we may draw on process types. Nominalisations are considered metaphors of transitivity (Taverniers, 2003, p. 8). Within the system of transitivity, six process types are distinguished:

\section{material}

'processes of doing, usually concrete, tangible actions' (Eggins, 2004, p. 215)

\section{mental}

processes describing 'what we think or feel', about cognition, affection and perception (Eggins, 2004, p. 225) 


\section{behavioural}

processes about 'physiological and psychological behaviour', 'action that has to be experienced by a conscious being' (Eggins, 2004, p. 233)

\section{verbal}

'processes of verbal action' (Eggins, 2004, p. 235)

\section{existential}

processes 'positing that "there was/is something"' (Eggins, 2004, p. 238)

\section{relational}

processes 'where things are stated to exist in relation to other things' (Eggins, 2004, pp. 237-238)

Studies of grammatical metaphor commonly make reference to these process types (see, e.g., Ravelli, 1988). Banks (2003, p. 137), in his diachronic analysis of the diachronic frequency of the use of nominalisations in scientific discourse, also investigates differences in the likelihood with which certain process types are nominalised. In a study of transitivity in English and German, Teich (2003, p. 182) notes 'no significant differences in the distribution of process types', and Hill-Madsen (2015, p. 205) draws on material and relational clauses in his analysis of grammatical metaphor in intralingual translation of patient information leaflets.

For the analysis, I have attributed each source text verb in the corpus to a process type. Needless to say, this method of analysis is highly subjective, as it involves my own analysis of the different process types. The problem of repeatability in process type analysis is a topic of much controversy in current Systemic Functional Linguistics (see O’Donnell, Zappavigna \& Whitelaw, 2008), but to my knowledge no viable alternative has been proposed.

I have, wherever possible, compared my analysis with the lists of verbs given in Banks (2003). The most common process types found in previous studies have been material and mental processes, of which (2) and (3), respectively, are examples.

(2) Increasing brand equity is best seen as a means to an end, one way to build customer equity. (HBR 1/10,94)

Die Steigerung des Werts einer Marke Den Wert einer Marke zu erhöhen kann wird bestenfalls als eine Methode zur Er- bestenfalls dazu dienen, ein wichtigeres reichung des wichtigeren Ziels, der Stei- Ziel zu erreichen: die Steigerung des gerung des Werts der Kunden, betrachtet. Kundenwerts. (HBM 3/10,86) (manuscript)

['The increase of a brand's value is best seen as a method for the achievement of the more important goal, the increase of ['To augment the value of a brand can the customer's value.']

(3) Managers' day-to-day (and moment-to-moment) behaviors matter not just because they directly facilitate or impede the work of the organization. (HBR 5/07,72) 
Das kurzfristige Verhalten von Managern ist nicht nur von entscheidender Bedeutung, weil es sich direkt hinderlich oder förderlich auf die Arbeit des Unternehmens auswirkt. (manuscript)

['Managers' short-term behaviour is not only of decisive significance because it directly affects impedingly or supportively the work of the organisation.']
Das kurzfristige Verhalten von Managern ist nicht nur von entscheidender Bedeutung, weil es sich direkt hinderlich oder förderlich auf die Arbeit innerhalb des Unternehmens auswirkt. (HBM 9/07,48)

['Managers' short-term behaviour is not only of decisive significance because it directly affects impedingly or supportively the work within the organisation.']

Table 1 lists the process types that verbs have been assigned to. In the case of material, mental and verbal processes, I only give a selection because all verbs would be too numerous to list.

Table 1. List of verbs classed as behavioural, verbal, existential and mental

\begin{tabular}{llllll}
\hline material & mental & behavioural & verbal & exist. & relational \\
\hline shape & believe & trust & describe (2) & exist (2) & own \\
operate & matter & support & assert & emerge & have (5) \\
tighten & affect & self-monitor & suggest & & be tied to \\
power & matter & determine & say (2) & & constitute \\
solve & think & concentrate & tell (3) & & lack \\
spur & concern & focus & call & & \\
drive & hear & become clear & criticize & & \\
act & decide & exhale & report (2) & \\
enter & assess & stay & name & & \\
perform & assume & devote & argue & & \\
deal & conceive & aim & ask (2) & & \\
fall short & value & intend & rearticulate & & \\
implement & acknowledge & get off & proclaim & & \\
pursue & consider & & respond & & \\
expand & feel & & predict & & \\
$\ldots$ & $\ldots$ & & $\ldots$ & & \\
\hline
\end{tabular}

The majority (78.93\%) of encountered processes are material (see Table 2), thus it is difficult to make meaningful statements about the other process types. While material processes occur roughly equally in retained and changed nominalisations, there is a statistically significant difference between the frequencies of mental processes, which occur more often where nominalisations were retained than where editors intervened $\left(\chi^{2}=6.51[\mathrm{df}=2], p=0.039\right)$. Due to the relatively small number of instances of mental process types this finding should be treated with care. Nevertheless, it may mean that editors are more likely to maintain a nominalisation if the source text verb is a mental process.

This may be owing to English-German typological contrasts or differences in communicative norms. Firstly, where English authors often begin a sentence with a finite clause such as I think or we believe, it is more common in German to use a (non-finite) adverbial construction like Meiner Meinung nach ('In my opinion') or Unserer Ansicht nach ('In our view') (see example (4); cf. also Baumgarten, 2008). Secondly, German has no verbal equivalent to the English verb to matter, 
so translators are often forced to nominalise, using, for instance, Auswirkungen/Bedeutung haben ('to have an effect/meaning') (see example 3 above).

(4) At Cummins, for example, Solso had to find a way to shift the culture from a 'best-efforts company,' where people felt that it was good enough to be smart and work hard and do the best they could, to 'believing that they actually had to deliver on their performance commitments.' (HBR 7/08,50)

Tim Solso von Cummins beispielswei- Tim Solso von Cummins beispielsweise musste einen Weg zur Änderung der Unternehmenskultur finden, weg von der ursprünglichen 'Best-Efforts-Mentalität', bei der es nach Ansicht der Mitarbeiter genügte, intelligent zu sein, hart zu arbeiten und ihr Bestes zu geben, und hin zu der 'Überzeugung, dass sie ihre Leistungsziele auch tatsächlich erreichen müssen'. (manuscript) se musste die gesamte Unternehmenskultur ändern - weg von der ursprünglichen 'Best-Efforts-Mentalität', bei der es nach Ansicht der Mitarbeiter genügte, intelligent $\mathrm{zu}$ sein, hart $\mathrm{zu}$ arbeiten und ihr Bestes zu geben, und hin zu der 'Überzeugung, dass sie ihre Leistungsziele auch tatsächlich erreichen müssen'. (HBM 8/08,20)

['Tim Solso from Cummins, for instance, had to find a way to a shift in the company culture, away from the original 'bestefforts mentality', in which, according to the view of staff, it was enough to be intelligent, to work hard and give their best, and towards the "belief that they actually had to reach their performance commit['Tim Solso from Cummins, for instance, had to shift the entire company cultureaway from the original 'best-efforts mentality', in which, according to the view of staff, it was enough to be intelligent, to work hard and give their best, and towards the 'belief that they actually had to reach their performance commitments'.'] ments'.']

Another explanation for such an effect might be that mental processes usually establish an addressee-oriented author-reader relationship, indicating affection and perception (Eggins, 2004, p. 225). German professional discourse is usually 'content-oriented' (Becher, House \& Kranich, 2009, p. 138; see also Hansen-Schirra et al., 2009, p. 110) so that language users may seek to establish more distance between author and reader. It is possible that editors and translators agree that the congruent, verbal forms of such processes are too personal for a text of this register and

Table 2. Editors' treatment of nominalisation analysed by process type

\begin{tabular}{lrrrr}
\hline Process type & \multicolumn{2}{c}{ Nom. retained } & \multicolumn{2}{c}{ Nom. changed } \\
& $\mathrm{n}$ & $\%$ & $\mathrm{n}$ & $\%$ \\
\hline material & 268 & 79.06 & 159 & 78.71 \\
mental & 47 & 13.86 & 18 & 8.91 \\
behavioural & 5 & 1.47 & 8 & 3.96 \\
verbal & 12 & 3.54 & 12 & 5.94 \\
existential & 1 & 0.29 & 2 & 0.99 \\
relational & 6 & 1.77 & 3 & 1.49 \\
\hline Total & 339 & 100.0 & 202 & 100.0 \\
\hline
\end{tabular}


therefore metaphorise them.

Consider once again example (4) above. Consider the three source text verbs to shift, to feel and to believe, where to shift is a material process while the other two are mental processes. In the manuscript, they have all been nominalised, as Änderung ('shift'), Ansicht ('view') and Überzeugung ('conviction'), respectively. In the published version, the nominalisations of the mental processes are retained, while the material process has been reverbalised to ändern ('to shift').

Overall, then, there is an indication that nominalisations whose base verb are mental processes are less likely to be reverbalised. However, for material processes, by far the largest group, no statistically significant difference has been recorded. Thus, process type does not seem to have a significant effect overall on the editors' decisions, but more extensive research into this issue is necessary.

\subsection{Nominal group structure}

The second possible explanation that has been analysed relates to the structure of the nominal group of which the nominalisation is the head noun. According to that hypothesis, editors are more likely to reverbalise constructions if the nominalisation is part of a nominal group with a certain complexity, that is, if the nominalisation is premodified or postmodified by a certain amount of attributes.

As noted above, German is considered to be more content-oriented than English, and HansenSchirra et al. (2009, p. 117) argue that this orientation towards content is partly achieved through a complex nominal group structure. In their study of the nominal group in English and German professional and newspaper discourse, Hansen-Schirra et al. (2009, p. 117) find that premodification is more common than postmodification in the German texts, and is achieved mainly through adverbs, determiners and participle phrases. Postmodification, as an important indicator of nominal style (Fabricius-Hansen, 1999, p. 204), is considered a marker of professional discourse in German, but is also found in popularising texts such as newspapers (Hansen-Schirra et al., 2009, p. 115). Genitive attributes are especially typical of German (Hansen-Schirra et al., 2009, p. 117) and commonly used in professional discourse (Banionyte, 2007; Roelcke, 1999, p. 81). Complex noun phrases have been shown to require more processing effort (Müller-Feldmeth et al., 2015, p. 251).

The corpus has been analysed with the Semantic Role Labeler (Björkelund, Hafdell \& Nugues, 2009; Björkelund, Bohnet, Hafdell \& Nugues, 2010) provided by the University of Stuttgart, and then manually corrected. I have analysed premodification and postmodification separately. Statistical significance is determined by the z-ratio test of significance of the difference between two independent proportions (see Hanneman, Kposowa \& Riddle, 2013, p. 294).

The results for the premodifiers are shown in Table 3. The category 'Article' contains cases where a definite or an indefinite article precedes the head noun. The category 'Pronoun' refers to cases where attributive pronouns (indefinite, possessive, interrogative, demonstrative and relative) occur. Adjectives that occur along with articles or pronouns were counted as part of those groups. The group 'Adjective' thus only contains adjectives that occur without a determiner. Finally, the group 'Adverb' contains adverbs.

Overall, no statistically significant difference in premodification is found in the data. Both retained and changed nominalisations have premodification in around $75 \%$ of cases, but the subcor- 
Table 3. Premodification of nominalised head nouns in retained $(n=339)$ and changed $(n=202)$ nominalisations

\begin{tabular}{lrrrrrr}
\hline Premodifier & \multicolumn{2}{c}{ Nom. retained } & \multicolumn{2}{c}{ Nom. changed } & $z$-ratio & $p$-value \\
\hline Article & 206 & $(60.77 \%)$ & 132 & $(65.7 \%)$ & -1.064 & 0.287 \\
Pronoun & 30 & $(8.85 \%)$ & 6 & $(2.97 \%)$ & 2.654 & 0.008 \\
Adjective & 20 & $(5.90 \%)$ & 10 & $(4.95 \%)$ & 0.467 & 0.641 \\
Adverb & 3 & $(0.89 \%)$ & 2 & $(0.99 \%)$ & - & - \\
\hline Total & 259 & $(76.40 \%)$ & 150 & $(74.26 \%)$ & 0.562 & 0.574 \\
\hline
\end{tabular}

Table 4. Postmodification of nominalised head nouns in retained $(n=339)$ and changed $(n=202)$ nominalisations

\begin{tabular}{lrrrrrr}
\hline Postmodifier & \multicolumn{2}{c}{ Nom. retained } & \multicolumn{2}{c}{ Nom. changed } & $z$-ratio & $p$-value \\
\hline Genitive attribute & 132 & $(38.94 \%)$ & 107 & $(52.97 \%)$ & -3.179 & 0.002 \\
Postnominal modifier & 52 & $(15.34 \%)$ & 29 & $(14.36 \%)$ & 0.310 & 0.757 \\
Phrasal genitive & 29 & $(8.55 \%)$ & 21 & $(10.40 \%)$ & -0.715 & 0.475 \\
Clausal modifier & 16 & $(4.72 \%)$ & 14 & $(6.93 \%)$ & -1.087 & 0.277 \\
\hline Total & 229 & $(67.55 \%)$ & 171 & $(84.65 \%)$ & -4.383 & 0.001 \\
\hline
\end{tabular}

pus of constructions where the nominalisation was changed has a higher number of attributive pronouns, which is highly statistically significant $(p<0.01)$. This may mean that if editors encounter a nominalisation that is premodified by a pronoun, they are less likely to reverbalise it.

Premodification and postmodification seem to be equally common in this dataset, and there is a notably low number of adverbs compared to the other means of premodification. Those observations stand in contrast to the results reported by Hansen-Schirra et al. (2009, p. 117) in their genre. Further research drawing on bigger corpora may produce genre differences between business and newspaper articles.

The analysis of postmodifiers is shown in Table 4. The types of postmodifiers that were found are genitive attributes, postnominal modifiers (which consist of prepositional phrases and adverbs), phrasal genitives and clausal modifiers such as object, relative and infinitive clauses. The changed nominalisations are postmodified in $85 \%$ of cases, while the constructions where the nominalisation was retained are only postmodified in $68 \%$ of cases, a difference that is highly statistically significant $(p<0.01)$. More specifically, changed nominalisations show a highly statistically significant difference $(p<0.01)$ in genitive attributes: half the constructions that editors reverbalised have a genitive postmodification, while only $39 \%$ of the retained nominalisations have one.

Thus, postmodification seems to be a factor that influences the editors' decision whether to reverbalise a construction or not. If a nominalised head noun is postmodified by a genitive attribute, according to the data analysed in the present corpus, editors are more likely to turn it back into a verb. A corpus example for this phenomenon is shown in (5). The nominalisations Nutzung ('use') and Wahrung ('maintenance') both have genitive attributes, and are converted back to verbs (in bold). The nominalisation Expansion ('expansion'), which has no genitive attribute but a prepositional one, is kept (in italics). The nominalisation of the adjective focused, Fokussierung, is not changed, but the genitive attribute is removed (in italics).

(5) The beauty of the PWP model is that it offers the potential for using operational strengths to expand into new areas while at the same time maintaining the operational excellence 
that comes from focused expertise. (HBR 9/09,90)

Die Attraktivität des PWP-Modells ist Der Charme des PWP-Modells besteht sein Potenzial bei der Nutzung be- darin, dass es die Möglichkeit bietet, betrieblicher Stärken zur Expansion in triebliche Stärken zur Expansion in neue neue Bereiche bei gleichzeitiger Wah- Bereiche zu nutzen und zugleich die Färung der hervorragenden betrieblichen Leistung, die sich aus der Fokussierung der einzelnen Einheiten ergibt. (manuscript) higkeit zu betrieblichen Spitzenleistungen zu wahren, die sich aus Spezialisierung und Arbeitsteilung ergibt. (HBM $12 / 09,78$ )

['The beauty of the PWP model is its po['The charm of the PWP model lies in tential for the use of operational strengths the fact that it offers the possibility to for the expansion into new areas with a concomitant maintenance of the excellent use operational strengths for the expansion into new areas and at the same time operational performance that comes from the focussing of individual units.']

to maintain the aptitude for operational excellence that comes from specialisation and division of labour.']

The explanation for this may have to do with comprehensibility. Postmodification increases information density and is generally assumed to make processing more difficult (Müller-Feldmeth et al., 2015, p. 251). It is possible that editors are conscious of the reputation of German as preferring the nominal style and of the 'clunkyness' of that style; therefore they might be trying to avoid it and make the language more accessible through a verbal style.

To investigate this further, we may measure information density by measuring the depth of the genitive attributes. The genitive attribute depth is the number of words that feature in a genitive attribute other than the head noun and a definite or indefinite article (see Müller-Feldmeth et al., 2015, p. 237). Thus, in example (6), the genitive attribute ihrer übergeordneten Mission has a depth of 2, ihrer Branchenmitbewerber has a depth of 1 and des Unternehmens has a depth of 0.

(6) These leaders are clearly energized by delivering on their larger mission, by soundly thrashing their competitors in the marketplace, and by directly connecting with the people in their firms. (HBR 7/08,50)

Diese Führungskräfte waren eindeutig Diese Führungskräfte beziehen ihre Momotiviert: durch die Verfolgung ih- tivation daraus, dass sie konsequent ihrer übergeordneten Mission, die kla- re höheren Ziele verfolgen, dass sie den re Überflügelung ihrer Branchenmitbe- Wettbewerbern die Rücklichter zeigen werber und ihre Beziehung zu den Mitar- und dass sie engen Kontakt zu ihren Mitbeitern des Unternehmens. (manuscript) arbeitern pflegen. (HBM 8/08,20)

['These leaders were clearly motivated: ['These leaders obtain their motivation through the pursuit of their larger mis- from the fact that they consequently folsion, the clear thrashing of their competit- low their higher targets, that they show ors and their connection to the employees the taillights to competitors and that of the company.'] they maintain close contact to their coworkers.'] 
Table 5. Genitive attribute depths

\begin{tabular}{lrrrrrr}
\hline Nominalisation & Depth 0 & Depth 1 & Depth 2 & Depth 3 & Depth 4 & Total \\
\hline retained & $50.0 \%$ & $41.6 \%$ & $6.1 \%$ & $1.5 \%$ & $0.8 \%$ & $100 \%$ \\
changed & $44.9 \%$ & $42.0 \%$ & $9.4 \%$ & $3.7 \%$ & $0.0 \%$ & $100 \%$ \\
\hline
\end{tabular}

Table 5 shows the percentages of each genitive attribute depth of the total number of genitive attributes. The genitive attributes given to the nominalised head nouns in the changed nominalisations have fewer depth 0 attributes and more depth 2 and 3 attributes, which confirms our observation that genitive attributes cause editors to dissolve the nominalised phrases they appear in.

In sum, the hypothesis that the structure and size of the nominal group may affect editors' decisions whether to retain a nominalisation or not has been confirmed. Premodification by pronouns seems to support a maintenance of the nominalisation, whereas postmodification by a genitive attribute will likely cause the editors to reverbalise the nominalisation.

\section{Conclusion}

The aim of this study has been to investigate possible linguistic features that may influence the editors' decisions to reverbalise some nominalisations but not others. For this purpose, I have analysed the process types of the source text verbs and the nominal group structure of the manuscript translation. The analysis of process types has shown that nominalisations of mental processes are more likely to be retained. That, however, can be explained by German communicative conventions, so that process type cannot be said to affect editors' decisions.

The analysis of nominal group structure has shown that the presence of pre- and postmodifiers do seem to have such an effect: nominalisations that are postmodified, especially by genitive attributes, seem more likely to be reverbalised, while premodification through pronouns may 'protect' the nominalisation.

These findings have given support to the main argument of this paper that editing can have a significant effect on the language of translation. Changes effected by editors on the translated text have been shown to be extensive, systematic and linguistically motivated. 202 out of 541 instances that the translator nominalised were turned back into verbs by the editor. The study thus shows that claims about literal translation of verbal forms should be made with care, as there is evidence that what appear to be literal translations may well have undergone two shifts in part of speech during the translation process.

\section{References}

Alves, F., Pagano, A., Neumann, S., Steiner, E. \& Hansen-Schirra, S. (2010). Translation units and grammatical shifts: Towards an integration of product- and process-based translation research. In G. M. Shreve \& E. Angelone (Eds.), Translation and cognition (pp. 109-142). Amsterdam: John Benjamins. doi:10.1075/ata.xv.07alv

Andújar Moreno, G. (2016). Traducción entregada frente a traducción publicada: Reflexiones sobre la normalización en traducción editorial a partir de un estudio de caso. Meta, 61(2), 396-420. doi:10.7202/1037765ar 
Baker, M. (1993). Corpus linguistics and translation studies: Implications and applications. In M. Baker, G. Francis \& E. Tognini-Bonelli (Eds.), Text and technology: In honour of John Sinclair (pp. 233-250). Amsterdam: John Benjamins. doi:10.1075/z.64.15bak

Banionyte, V. (2007). Genitivattribut und nominale Phrase in der deutschen Wissenschafts- und Fachsprache. Žmogus ir žodis, 9(3), 5-11. Retrieved from http://www.biblioteka.vpu.lt/ zmogusirzodis/english/forlange/svetkale.htm

Banks, D. (2003). The evolution of grammatical metaphor in scientific writing. In A.-M. Vandenbergen, M. Taverniers \& L. J. Ravelli (Eds.), Grammatical metaphor: Views from Systemic Functional Linguistics (pp. 127-148). Amsterdam: John Benjamins. doi:10.1075/cilt.236. 07ban

Baumgarten, N. (2008). Writer construction in English and German popularised academic discourse: the uses of we and wir. Multilingua, 27, 409-438. doi:10.1515/MULTI.2008.019

Becher, V., House, J. \& Kranich, S. (2009). Convergence and divergence of communicative norms through language contact in translation. In K. Braunmüller \& J. House (Eds.), Convergence and divergence in language contact (pp. 125-152). Amsterdam: John Benjamins. doi:10. 1075/hsm.8.06bec

Bisiada, M. (2016). 'Lösen Sie Schachtelsätze möglichst auf': The impact of editorial guidelines on sentence splitting in German business article translations. Applied Linguistics, 37(3), 354-376. doi:10.1093/applin/amu035

Björkelund, A., Bohnet, B., Hafdell, L. \& Nugues, P. (2010). A high-performance syntactic and semantic dependency parser. Coling 2010: Demonstration Volume, 33-36. Retrieved from http://www.aclweb.org/anthology/C/C10/C10-3009.pdf

Björkelund, A., Hafdell, L. \& Nugues, P. (2009). Multilingual semantic role labeling. Proceedings of The 13th Conference on Computational Natural Language Learning (CoNLL-2009), 4348. Retrieved from http://www.aclweb.org/anthology/W/W09/W09-1206.pdf

Burrough-Boenisch, J. (2003). Shapers of published NNS research articles. Journal of Second Language Writing, 12(3), 223-243. doi:10.1016/S1060-3743(03)00037-7

Eggins, S. (2004). An introduction to systemic functional linguistics (2nd). London: Bloomsbury.

Eve, M. P. (2016). 'You Have to Keep Track of Your Changes': The version variants and publishing history of David Mitchell's Cloud Atlas. Open Library of Humanities, 2(2), e1. doi:10. 16995/olh.82

Fabricius-Hansen, C. (1999). Information packaging and translation: Aspects of translational sentence splitting (German-English/Norwegian). In M. Doherty (Ed.), Sprachspezifische Aspekte der Informationsverteilung (pp. 175-214). Berlin: Akademie Verlag.

Fantinuoli, C. \& Zanettin, F. (2015). Creating and using multilingual corpora in translation studies. In C. Fantinuoli \& F. Zanettin (Eds.), New directions in corpus-based translation studies (pp. 1-10). Berlin: Language Science Press. Retrieved from http://langsci-press.org/catalog/ view/76/67/277-1

Filippakopoulou, M. (2008). Translation drafts and the translating self. In P. Nikolaou \& M.-V. Kyritsi (Eds.), Translating selves: Experience and identity between languages and literatures (pp. 19-36). London: Continuum.

Hanneman, R. A., Kposowa, A. J. \& Riddle, M. (2013). Basic statistics for social research. San Francisco: Wiley. 
Hansen-Schirra, S., Hansen, S., Wolfer, S. \& Konieczny, L. (2009). Fachkommunikation, Popularisierung, Übersetzung: Empirische Vergleiche am Beispiel der Nominalphrase im Englischen und Deutschen. Linguistik online, 39(3), 109-118. doi:10.13092/lo.39.480

Hartmann, R. R. K. (1980). Contrastive textology: Comparative discourse analysis in applied linguistics. Heidelberg: Julius Groos.

Hartmann, R. R. K. (1981). Contrastive textology and translation. In W. Kühlwein, G. Thome \& W. Wilss (Eds.), Kontrastive Linguistik und Übersetzungswissenschaft (pp. 200-208). München: Fink.

Harvey, K. (2003). 'Events' and 'Horizons': Reading ideology in the 'Bindings' of translations. In M. C. Pérez (Ed.), Apropos of ideology (pp. 43-69). Manchester: St Jerome.

Heyvaert, L. (2003). Nominalization as grammatical metaphor: On the need for a radically systemic and metafunctional approach. In A.-M. Vandenbergen, M. Taverniers \& L. J. Ravelli (Eds.), Grammatical metaphor: Views from Systemic Functional Linguistics (pp. 65-100). Amsterdam: John Benjamins. doi:10.1075/cilt.236.05hey

Hill-Madsen, A. (2015). The 'unpacking' of grammatical metaphor as an intralingual translation strategy: From de-metaphorization to clausal paraphrase. In K. Maksymski, S. Gutermuth \& S. Hansen-Schirra (Eds.), Translation and comprehensibility (pp. 195-226). Berlin: Frank \& Timme.

Holmes, J. S. (1988). Translated! Papers on literary translation and translation studies. Amsterdam: Rodopi.

Jansen, H. \& Wegener, A. (Eds.). (2013). Authorial and editorial voices in translation. Montreal: Editions québécoises de l'oeuvre.

Kenny, D. (2009). Corpora. In M. Baker \& G. Saldanha (Eds.), Routledge encyclopedia of translation studies (2nd ed., pp. 59-62). London: Routledge.

Krein-Kühle, M. (2003). Equivalence in scientific and technical translation: A text-in-contextbased study (Doctoral dissertation, University of Salford). Retrieved from http://usir.salford. ac.uk/14846/

Kruger, H. (2012). A corpus-based study of the mediation effect in translated and edited language. Target, 24(2), 355-388. doi:10.1075/target.24.2.07kru

Manenti, D. (2010). Inside the black box: Notes around the editorial manipulation of the Journal of Katherine Mansfield. La Libellula, 2, 172-178.

Mossop, B. (2007). Empirical studies of revision: What we know and need to know. The Journal of Specialised Translation, 8, 5-20. Retrieved from http://www.jostrans.org/issue08/art_ mossop.pdf

Mossop, B. (2014). Revising and editing for translators (3rd ed.). Abingdon: Routledge. (Original work published 2001)

Müller-Feldmeth, D., Held, U., Auer, P., Hansen-Morath, S., Hansen-Schirra, S., Maksymski, K., ... Konieczny, L. (2015). Investigating comprehensibility of German popular science writing. In K. Maksymski, S. Gutermuth \& S. Hansen-Schirra (Eds.), Translation and comprehensibility (pp. 227-261). Berlin: Frank \& Timme.

Munday, J. (2013). The role of archival and manuscript research in the investigation of translator decision-making. Target, 25, 125-139. doi:10.1075/target.25.1.10mun 
O’Donnell, M., Zappavigna, M. \& Whitelaw, C. (2008). A survey of process type classification over difficult cases. In C. Jones \& E. Ventola (Eds.), From language to multimodality: New developments in the study of ideational meaning (pp. 47-64). London: Equinox. doi:10. 1558/equinox.21979

Olohan, M. (2004). Introducing corpora in translation studies. Abingdon: Routledge.

Purcell, G. P., Donovan, S. L. \& Davidoff, F. (1998). Changes to manuscripts during the editorial process: Characterizing the evolution of a clinical paper. Journal of the American Medical Association, 280(3), 227-228. doi:10.1001/jama.280.3.227

Ravelli, L. J. (1988). Grammatical metaphor: An initial analysis. In E. Steiner \& R. Veltman (Eds.), Pragmatics, discourse and text: Some systemically inspired approaches (pp. 135147). London: Frances Pinter.

Roelcke, T. (1999). Fachsprachen. Berlin: Schmidt.

Sinner, C. (2012). Fictional orality in romance novels: Between linguistic reality and editorial requirements. In J. Brumme \& A. Espunya (Eds.), The translation of fictive dialogue (pp. 119136). Amsterdam: Rodopi.

Taverniers, M. (2003). Grammatical metaphor in SFL: A historiography of the introduction and initial study of the concept. In A.-M. Vandenbergen, M. Taverniers \& L. J. Ravelli (Eds.), Grammatical metaphor: Views from Systemic Functional Linguistics (pp. 5-33). Amsterdam: John Benjamins. doi:10.1075/cilt.236.02tav

Teich, E. (2003). Cross-linguistic variation in system and text. Berlin: de Gruyter.

Toury, G. (1995). Descriptive translation studies and beyond. Amsterdam: John Benjamins.

Utka, A. (2004). Phases of translation corpus: Compilation and analysis. International Journal of Corpus Linguistics, 9(2), 195-224. doi:10.1075/ijcl.9.2.03utk 